\title{
THE SLOVENIAN PERSPECTIVE OF A MAIN HEARING IN AN ADMINISTRATIVE DISPUTE
}

Purpose. This article deals with the current legislation and practice of the Republic of Slovenia concerning main hearing in an administrative dispute. Besides, the article is devoted to legal analysis of Slovenian case law and to examination of demands, established by the European Court of Human Rights regarding the right to a fair trial, particularly the right to a main hearing.

Methods. To conduct the research successfully, the author used the following methods of scientific knowledge: logical (analysis, synthesis, induction, deduction), historical, systemic and formally dogmatic.

Results. An integral part of the right to a fair trial is formed by the public nature of a trial, which is, in case of administrative dispute, realised on the basis of a concluded main hearing. Its aim is to ensure a democratic trial, exercise public control over a trial, as well as exercise the right of parties to the dispute and other participants in the procedure to be heard in court. This piece discusses the meaning and the role of the main hearing in an administrative dispute. It examines both legal and general social reasons which speak in favour of the execution of the main hearing. The most important decisions of the European Court of Human Rights and of domestic courts regarding the rights to the main hearing are analysed. The statistical data of the Slovenian Administrative Court on conducting main hearings as an indicator of ensuring the right to a fair trial in the Republic of Slovenia is researched.

The author has reached a conclusion that the main hearing in an administrative dispute is of crucial importance with respect to exercising the right to adversarial procedure and right to fair procedure.

Conclusions. Despite the numerous advantages of decision-making in an administrative dispute after a completed main hearing, it needs to be taken into account that the obligation of decision-making after a main hearing is not absolute. Consideration of omitting a main hearing ought to be inspired by the criteria adopted by the European Court of Human Rights, as they provide for a high level of protection of a main hearing as human right.

Key words: main hearing, administrative dispute, human right, administrative court, right to a fair trial, European Court of Human Rights. 


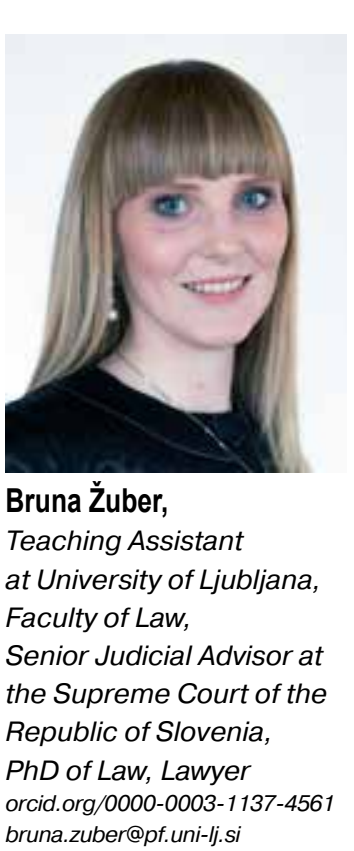

bruna.zuber@pf.uni-lj.si

\section{Introduction}

The principle of oral, direct and public trial, imposing on courts to decide on the rights and duties of parties in the procedure on the basis of a main hearing, is supported by both international as well as Slovenian national law (Žuber, 2018; Rosas, 2014). It seems inconceivable for courts to decide on civil disputes or criminal charges without the main hearing, whereas in an administrative dispute, designated to conduct judicial control over legality of administrative operation and acts, the position somewhat differs.

In the Republic of Slovenia (hereinafter referred as Slovenia) an administrative dispute is a dispute which, considering its concept, typically follows the administrative procedure, whereby an administratively final decision has been (or at least ought to have been) passed after establishing the actual facts of the case by means of proper application of substantive law in line of predetermined procedural rules (Kerševan, 2002; Kerševan, Androjna, 2017). Notwithstanding the above specificities, as defined by legislators, a main hearing must form part of decision-making in an administrative dispute due to its significance. However, this statutory rule is unfortunately not applied in practice, since the Administrative Court of the Republic of Slovenia (hereinafter referred as Administrative Court) mostly adjudicates in a session as opposed to following the main hearing. Consequently, the Supreme Court of the Republic of Slovenia (hereinafter referred as Supreme Court) has long been drawing attention to the duty of executing main hearings in the Administrative Court. Moreover, the issue of failing to conduct the main hearing in an administrative dispute in Slovenia was first raised at the European court of Human Rights (hereinafter referred as ECtHR) in 2018.

This piece discusses the role and the meaning of the main hearing in an administrative dispute in Slovenia. It examines both legal and general social reasons which speak in favour of the execution of the main hearing, as well as presents a few of the most relevant opinions of the ECtHR concerning the execution of main hearings in administrative dispute. Although we distinguish two fundamental types of administrative dispute in Slovenia, i.e. dispute on legality of individual administrative act and dispute of full jurisdiction (Kerševan, Androjna, 2017), the article due to rules on article's volume focuses on common features of a main hearing conducted at the first-instance court, i. e. the Administrative Court. 
The aim of this article is to provide scientific analysis of conducting a main hearing in an administrative dispute and underline its characteristics in Slovenian theory and practice. The goal of research is also the consideration of the ECtHR's most important opinions on conducting a main hearing in an administrative dispute. The tasks of the paper are as following: to analyse legal basis for conducting main hearing in administrative dispute, to explore the statistical data of the Slovenian Administrative court on conducting main hearings, to find out whether the number of conducted main hearings in Administrative court is a proper indicator of ensuring the right to a fair trial, to investigate advantages and disadvantages of conducting a main hearing, to analyse most important opinions of the ECtHR on conducting main hearings in administrative dispute, and to determine the importance of such opinions.

\section{Legal basis for conducting main hearing in an administrative dispute}

The right to a trial at a main hearing is provided for by article 6 of European Convention on Human Rights (right to a fair trial) and article 47 of EU Charter of Fundamental Rights (right to an effective remedy and to a fair trial) at the international level, whereas at the national level it is provided for by the Constitution of the Republic of Slovenia (hereinafter referred as the Constitution) in articles 22 (equal protection of rights), 23 (right to judicial protection) and 24 (public nature of court proceedings).

The institution of a main hearing in an administrative dispute in Slovenia is regulated by the Slovenian act on administrative dispute (Administrative Dispute Act, hereinafter referred as ADA) in articles from 51 to 59 (Državni zbor Republike Slovenije, 2006). Article 51 of ADA establishes the rule that the Administrative Court shall adjudicate after the main hearing and lays down a general rule stating that a main hearing is intended to take evidence. Subsequent articles stipulate the rules on the institution, conduct, and implementation of a main hearing. In addition to ADA, special rules concerning the implementation of a main hearing are provided by certain acts (e. g. acts in the field of insurance, auditing, the financial instruments market).

In exceptional circumstances, which are stipulated in article 59 of ADA, the court may adjudicate in a session (Breznik, Kerševan, 2008). In line with article 59, paragraph 2 of ADA the court may adjudicate in a session in the event of one of the following situations:

- facts of the case that were the basis for the issuing of the administrative act between the plaintiff and defendant are not contentious;

- if it is already evident on the basis of the action, contested act and administrative files, that the action needs to be upheld and the administrative act annulled and the accessory participant with an opposing interest did not take part in the administrative dispute;

- if the facts of the case between the plaintiff and the defendant are contentious, but the parties state only new facts and new evidence, which the court may not take into consideration (due to belatedness) or the proposed new facts and evidence are not relevant for the decision;

- if there is a dispute between the same parties where the factual and legal basis are similar, and the court has already passed a final decision on this issue.

Besides, the court always adjudicates in a session regarding disputes on the legality of acts of electoral bodies (article 59, paragraph 4 of ADA). Where the court adjudicates 
in a session, it may only make its decision based on the facts of the case established in the administrative procedure (article 60 of ADA). One of the most important differences between adjudicating after a completed main hearing and adjudicating in a session is that the session shall not be public (article 59, paragraph 5 of ADA).

In Slovenia, failure to conduct a main hearing is an encroachment on human right, which is only permitted exceptionally if so provided by an Act taking into account the principle of proportionality (see: articles 2 and 15 of the Constitution, decisions of the Constitutional Court of Slovenia № U-197/02, № Up-778/04, № Up-1055/05). At this point it is worth recalling the constitutional contention of several sectoral acts excluding a main hearing in all cases beforehand (e. g. article 448 of Insurance Act) or regulating that as a rule, the court shall decide without a hearing, (e. g article 115 of Auditing Act), thereby rendering the execution of a main hearing unnecessary, which is unacceptable from the point of view of the law.

Failure to conduct a main hearing is a violation of human rights, and therefore, is it upon the Administrative Court to state reasons for the non-execution at all times, regardless of whether adjudicating based on provisions of ADA or in view of sectoral acts. Failure to provide statements of grounds is a violation of the right to receive reasons of the decision (see also: decisions of the Constitutional Court of Slovenia № Up-164/14 and № Up-434/14). In recent years, the Supreme Court has stepped up the required standard of reasoning decisions concerning the execution of a main hearing. According to recent case law, arguments of the Administrative Court should be compelling, exhaustive, as well as clearly stating reasons why the proposed evidence would not affect the decision, as these arguments are inextricably linked to the decision of executing a main hearing (Žuber, 2018; see also the following decisions of the Supreme Court: № X Ips 387/2015, № X Ips 233/2014, № X Ips 275/2014).

\section{Main hearings in Administrative Court's practice}

Even though regulatory framework in ADA defines the conduct of a main hearing as a rule and adjuticating in a session as an exception, the reality of our practice in view of the conduct of a main hearing is quite the contrary in Slovenia. The table below shows conducts of main hearings in an administrative dispute in the Administrative Court since 2013.

Table 1

Conducts of main hearings in the Administrative Court from 2013 to 2018

\begin{tabular}{|c|c|c|c|}
\hline Year & Caseload & $\begin{array}{c}\text { oo of cases decided } \\
\text { on the merits }\end{array}$ & $\begin{array}{c}\text { No of conducted } \\
\text { main hearings }\end{array}$ \\
\hline 2018 & 3540 & 2139 & 144 \\
\hline 2017 & 3976 & 1816 & 85 \\
\hline 2016 & 2972 & 2050 & 85 \\
\hline 2015 & 2953 & 2438 & 39 \\
\hline 2014 & 3291 & 2776 & 49 \\
\hline 2013 & 3280 & 2703 & 68 \\
\hline
\end{tabular}

Figures in table 1 indicate that the number of conducted main hearings somewhat increased in 2016 for the first time, and then again in 2018. Increase in conducted main 
hearings in 2016 can be attributed to the Supreme Court, whose decisions reminded the Administrative Court of more frequent executions of main hearings (on this see the decisions of the Supreme Court № X Ips 233/2014, № X Ips 275/2014). The reason for more frequent executions of main hearings in 2018 most likely lies in an extensively discussed ECtHR's judgement in case of the Mirovni inštitut v. Slovenia (№ 32303/13, 13 March 2018). This was the first case where ECtHR faced allegations of failing to conduct a main hearing in an administrative dispute in Slovenia. Infringement of article 6 of European Convention on Human Rights was established in this case, due to the fact that the Administrative Court failed to take position on the requirement of the applicant to conduct a main hearing, nor did the Court state any reasons for failing to conduct a main hearing. The applicant requested the execution of a main hearing due to factual and legal errors allegedly committed by the Ministry of Education when allocating funds following a call for research projects, to which the applicant had applied but had not been granted the funding. Furthermore, the applicant requested examination of witnesses due to alleged errors that had been committed (impartiality of certain assessors, disregard of criteria).

It can be concluded that the trend of a gradual increase in the execution of main hearings can be considered positive; however, the number of executed main hearings does not reflect the basic statutory rule in ADA, namely that the Administrative Court in an administrative dispute adjudicates after a completed main hearing. On the other hand, this does not imply that there is a systematic problem in administrative disputes in Slovenia with regard to violations of the right to a fair trial due to failure to execute main hearings. This is also supported by the fact that in the last five-year period (2014-2018), ECtHR has found a violation of a right to a fair trial in 13 cases against Slovenia, while it has found violations in 33 cases in the prior five-year period (2013-2009), meaning that, in comparison to the latter time period, the number of determined violations of a right to a fair trial against Slovenia has been reduced by $60 \%$ in the last five years.

\section{4. (Dis)advantages of decision-making in administrative dispute after the main} hearing

From the perspective of an outside observer, the execution of the main hearing ensures public nature of a trial, whereas from the perspective of parties and other participants in the procedure, it represents a means to personally present arguments to the court. An executed main hearing enhances predictability of parties regarding the proceedings and the outcome of the procedure, as well as prevents a surprise judgement, which occurs when the court shall unexpectedly base its decision on a legal basis which a party with due diligence could not have anticipated. Consequently, completely different facts and evidence from those stated by the party turn out to play a prominent role in the dispute. Surprise judgement is prohibited in the Slovenian legal system, so as to prevent situations when a party loses the possibility to state facts of crucial importance due to the fact that the court has based its decision on a legal basis which the party with due diligence could not have anticipated (see decision of the Supreme Court № II Ips 75/2016, 1 February 2018). Decision of the Supreme Court № II Ips 75/2016 clearly states that a means of preventing surprise judgements is the substantive conduct of proceedings, which is most widely implemented precisely in main hearings and within which the court draws a party's attention to the overlooked legal basis, as well as reveals its own, distinct and 
unanticipated point of view of the law, and reminds the party of the legal basis upon which it intends to base the dispute resolution.

On the other hand, failure to conduct the main hearing can result in deficient presenting of exculpatory evidence and deficient substantive conduct of proceedings, due to which a party initially has no possibility of supplementing allegations and applications for evidence (Breznik, Kerševan, 2008). Due to adjuticating after a completed main hearing, owing to the predominance of the oral proceeding principle over the written form principle, parties obtain the impression of a fairer decision (Žuber, 2018). All of the indicated beyond doubt enhances the legitimacy of exercising of judicial authority and contributes to the reputation of the judiciary in general public. The execution of a main hearing does not only benefit parties and other participants in the procedure, but also the Administrative Court. The main hearing enables the court to examine facts and take evidence, get directly acquainted with legal and factual aspects of the procedure, as well as clarify relevant issues regarding the principle of open trial.

As it is the case with the majority of other legal institutions, execution of a main hearing in an administrative dispute can lead to objections (Samuels, 2005), one of the most frequent ones being that conduct of a main hearing burdens and prolongs administrative dispute. The allegation is by all means unfounded in case a main hearing is thoroughly prepared and executed, at best contributing to the acceleration of proceedings (Pirnat, Kerševan, 2005). There is further allegation stating that a completed main hearing fails to serve its purpose in cases when Administrative Court grants the action, annulus the administrative act contested in the administrative dispute and returns the case to administrative authority for re-examination. The allegation can be disputed on the basis of the primary objective of a main hearing, i. e. due to taking evidence (article 51, paragraph 2 of ADA). The right of taking evidence is not an absolute right, since the court is not obligated to take evidence in case it is belated, unsubstantiated, unnecessary, irrelevant, or inappropriate (see decisions of the Supreme Court № X Ips 220/2016, 17 May 2017, № X Ips 233/2014, 3 March 2016, № Ips 114/2013, 23 October 2014). On the other hand, the Administrative court shall not dismiss the conduct of a main hearing as a consequence of anticipated evaluation of evidence, as it is prohibited (see decisions of the Supreme Court № X Ips 220/2016, № X Ips 233/2014). It can only be accepted in case the Administrative Court presents comprehensive and convincing arguments as to why adduced evidence cannot affect the decision: it should start from the assumption that the adduced evidence would succeed in confirming the party's position, regardless of which the court would decide in the same manner considering other compelling evidence (see decision of the Supreme Court № X Ips 233/2014 and decision of the Constitutional Court № Up-219/2015, 19 May 2016). In case the Administrative Court establishes that an administrative authority has unjustifiably (without legally permissible grounds) rejected applications for evidence, and in order to eliminate violations of the rules of the procedure this evidence should be presented, the court itself is obligated to take the evidence at the main hearing. The court can avoid the obligation only in case taking evidence would shift the entire burden of proof from administrative authority to Administrative Court. In case of establishing facts which are different from those established in the administrative decision the Administrative Court can, if the conditions have 
been met, decide on the merits of the case on its own or annul the administrative act contested in the administrative dispute and return the case to administrative authority for re-examination. The administrative authority is bound by substantive final judgement as regards the operative part of judgement, as well as main reasons, which justify the operative part of judgement. Substantive final is any decision whereby the court substantively ruled on the legality of final administrative act. The authority that issued the administrative act in new adjudication is not bound only by the legal opinion of the court regarding the application of substantive law and its positions on the procedure (article 64 of ADA), but also by facts established through a decision, since facts of a case are inextricably related to legal positions regarding the right to taking evidence and the operative part of judgement (see decision of the Supreme Court № X Ips 220/2016). Indeed, the latter points to an unsubstantiated allegation claiming that in case of annuling the contested act and a repeated decision of an administrative authority, a completed main hearing and evidence taken have no relevance.

\section{Main hearing in the light of ECtHR's jurisprudence}

European Convention on Human Rights does not provide the right to a fair trial in case of deciding on each right or obligation of national law; however, to ensure guarantee of a fair procedure it is essential that there is criminal charge or civil nature of a right, which the ECtHR explains autonomously. If the right has been defined as civil under national law of a state, the ECtHR shall not assess its content or its effects, but regards it as such. If that is not the case, the key factor of the assessment is the pecuniary nature of the considered rights or obligations. If the right by itself is not of pecuniary nature, it is crucial whether it causes pecuniary effects for a party (Harris, 2014). Where issues that are governed by public law are decisive in determining private rights and obligations, they fall within article 6, paragraph 1 of European Convention on Human Rights (Schabas, 2015).

The ECtHR decided based on the above criteria that procedural guarantees under article 6 apply to expropriation permits and for issuance of building permits (decision in the case Sporrong and Lönnroth v. Sweeden, № 7152/75, 23 September 1982, paragraph 83 and 79), permissions to sell land (decision in the case Ringeisen v. Austria, № 2614/65, 16 July 1971, paragraph 94), authorizations to operate a private clinic (decision in the case decision in the case König v. Germany, № 6232/73, 28 June 1978, paragraph 94 and 95) and licences to serve alcoholic beverages (decision in the case Tre Traktörer AB v. Sweden, № 10873/84, 10 October 1985, paragraph 43). The ECtHR extended the scope of article 6, paragraph 1 of European Convention on Human Rights to tender procedures (decision in the case Regner v. Czech Republic, № 35289/11, 19 September 2017 and decision in the case Mirovni inštitut v. Slovenia), however, on the other hand, decided that the civil nature of a right shall not apply to electoral dispute, in particular the right to stand for election and retain one's seat (decision in the case Pierre-Bloch v. France, № 120/1996/732/938, 21 October 1997, paragraph 51) and in tax matters, except in tax penalty cases (decision in the case Ferrazzini v. Italy, № 44759/98, 12 July 2001, paragraph 28 and decision in the case Jussila v. Finland, № 73053/01, 23 November 2006).

As it results from case law of the ECtHR, the right to a main hearing, which is based on article 6, paragraph 1 of European Convention on Human Rights, is not absolute 
(Žuber, 2018; Helmreich, 2013). Failure to conduct a main hearing is permitted if a party to the dispute renounces the right to a main hearing (explicitly or in a manner that the party does not request to conduct a main hearing). Furthermore, the obligation to conduct a main hearing can be excluded by exceptional circumstances that justify dispensing with a hearing (decision in the case Salomonsson v. Sweden, № 38978/97, 12 November 2002, paragraph 34).

There are a number of interesting cases concerning failure to conduct a main hearing due to dispensing, such as, when party to the dispute renounces the right to a main hearing in the first instance procedure and requests a main hearing in an appeal procedure. In such cases the ECtHR applies a less stringent standard for the execution of an oral hearing, however, it takes into consideration as key circumstances, whether facts could have been established without a main hearing and if a party requested taking new evidence (decision in the case Miller v. Sweden, № 55853/00, 8 February 2005, decision in the case Döry v. Sweden, № 28394/95, 12 November 2002, decision in the case Salomonsson v. Sweden).

When the court of first instance represents the only instance, a main hearing is required unless there are exceptional circumstances that justify dispensing with such a hearing. The fundamental principle when it comes to deciding on conducting a main hearing in such cases is the principle of fair trial (decision in the case Schädler-Eberle v. Liechtenstein, № 56422/09, 18 July 2013, paragraph 99). According to the EctHR, conducting a main hearing is not required in procedures not contesting credibility of findings or proper establishment the actual facts of the case, as well as those in which the court can make a fair and reasonable decision on the basis of written statements of the parties (decision in the case Jussila v. Finland, paragraph 99). Despite the stated position, the ECtHR highlights that the existence of exceptional circumstances requires an assessment for each individual case (decision in the case Miller v. Sweden). The ECtHR attaches great importance to reasonableness of the reasoning why conducting a main hearing failed (decision in the case Jussila v. Finland, paragraph 48, decision in the case Becker v. Austria, № 19844/08, 11 June 2015, paragraphs 39-42, decision in the case the Peace institute v. Slovenia, paragraph 44). Unless it is certain of exceptional circumstances that justify dispensing with a hearing, the ECtHR decides in favour of the applicant (decision in the case Karajanov v. the former Yugoslav Republic of Macedonia, № 2229/15, 6 April 2017 and decision in the case Mirovni inštitut v. Slovenia).

\section{Conclusions}

A main hearing in an administrative dispute provides for a public nature of a trial and holds significant meaning for the participants in the procedure in the light of exercising the right to adversarial procedure and right to a fair procedure. A main hearing presents a participant's day in court, and therefore enhances predictability of the procedure, as well as exerts a positive impact on confidence in fair conduct of courts. A conducted main hearing is relevant to the Administrative Court as well, since it enables the court to get directly acquainted with both legal and factual considerations of the proceedings, establish facts, as well as take evidence. A main hearing enables the court to fully realise the substantive conduct of proceedings, which, in turn, precludes surprise judgements. 
Despite the numerous advantages of decision-making in an administrative dispute after a conducted main hearing, it needs to be taken into account that the obligation of a decision after a completed main hearing is not absolute, be it under Slovenian regulation or in accordance with the ECtHR's practice. In cases when the Administrative Court adjudicates on omitting a main hearing based on national regulations it is obligated to take into account the positions defined by the EctHR, since they provide for a high level of protecting a main hearing as a human right.

Finally, it is worth noting that the responsibility of deciding to conduct a main hearing lies not only with the judiciary, but also legislative branch of government. Special rules regarding conduct of a main hearing in sectoral acts ought to be regulated more consistently and precisely, but above all, in principle there should not exist rules stipulating the omission of a main hearing in certain types of disputes. The decision whether or nor to conduct a main hearing in a specific case should be left to courts, and they, in turn, should not be restricted by abstract statutory rules that absolutely exclude adjutication after a completed main hearing in certain cases.

\section{Bibliography:}

1. Zakon o upravnem sporu s komentarjem / J. Breznik, E. Kerševan (eds.). Ljubljana : GV založba, 2008. 529 p.

2. Dekleva N. Pomen glavne obravnave pri odločanju v upravnem sporu polne jurisdikcije. Javna uprava. 2017. № 54. P. 15-32.

3. Law of the European Convention on Human Rights / D. Harris, M. O'Boyle, E. Bates, C. Buckley, P. Harvey, M. Lafferty, P. Cumper, Y. Arai, H. Green. Oxford ; New York : Oxford University Press, 2014. 1006 p.

4. Helmreich M. Absence of an Oral Hearing before the Independent Administrative Panel. Vienna Online Journal on International Constitutional Law. 2013. Vol. 7. P. 541-546.

5. Kerševan E. Upravni spor: koncept upravnosodnega nadzora nad upravo. Ljubljana : Inštitut za primerjalno pravo pri Pravni fakulteti, 2002. 150 p.

6. Kerševan E., Androjna V. Upravno procesno pravo: upravni postopek in upravni spor. Ljubljana : IUS Software ; GV založba, 2017. 714 p.

7. Pirnat R., Kerševan E. Nekaj misli o zvečanju učinkovitosti upravnega spora. Podjetje in delo. 2005. № 31. P. 1039-1050.

8. Rosas A. Oral Hearings before the European Court of Justice. Maastricht Journal of European and Comparative Law. 2014. Vol. 21. P. 596-610.

9. Samuels A. A Right to an Oral Hearing in Quasi-Judicial Proceedings? The Cambridge Law Journal. 2005. Vol. 64. P. 523-527.

10. Schabas W. The European Convention on Human Rights: a commentary. Oxford : Oxford University Press, 2015. 1308 p.

11. Pomen prakse in zahtev ESČP za izvedbo glavne obravnave v upravnem sporu: študija projekta / B. Žuber (ed.). Ljubljana : Univerza v Ljubljani, 2018. 218 p.

12. Ustava Republike Slovenije (URS). URL: http://pisrs.si/Pis.web/pregledPredpisa?id=USTA1.

13. Zakon o upravnem sporu (ZUS-1). URL: http://pisrs.si/Pis.web/pregledPredpisa?id=ZAKO4732.

14. Zakon o zavarovalništvu (ZZavar-1). URL: http://www.pisrs.si/Pis.web/pregledPredpisa?id=ZAKO6183.

15. Zakon o revidiranju (ZRev-2). URL: http://www.pisrs.si/Pis.web/pregledPredpisa?id=ZAKO5273. 


\section{References:}

1. Breznik, J., Kerševan, E. (eds.) (2008). Zakon o upravnem sporu s komentarjem [Administrative Dispute Act with Commentary]. Ljubljana: GV založba [in Slovene].

2. Dekleva, N. (2017). Pomen glavne obravnave pri odločanju v upravnem sporu polne jurisdikcije [The importance of the main hearing in the administrative dispute of full jurisdiction]. Javna uprava, no. 54, pp. 15-32 [in Slovene].

3. Harris, D. et al. (2014). Law of the European Convention on Human Rights. Oxford; New York: Oxford University Press [in English].

4. Helmreich, M. (2013). Absence of an Oral Hearing before the Independent Administrative Panel. Vienna Online Journal on International Constitutional Law, vol. 7, pp. 541-546 [in English].

5. Kerševan, E. (2002) Upravni spor: koncept upravnosodnega nadzora nad upravo [Administrative dispute: the concept of judicial control over administration]. Ljubljana: Inštitut za primerjalno pravo pri Pravni fakulteti [in Slovene].

6. Kerševan, E., Androjna, V. (2017). Upravno procesno pravo: upravni postopek in upravni spor [Administrative procedural law: administrative dispute and administrative procedure]. Ljubljana: IUS Software; GV založba [in Slovene].

7. Pirnat, R., Kerševan, E. (2005). Nekaj misli o zvečanju učinkovitosti upravnega spora [Some thoughts about increasing the efficiency of administrative dispute]. Podjetje in delo, no. 31, pp. 1039-1050 [in Slovene].

8. Rosas, A. (2014). Oral Hearings before the European Court of Justice. Maastricht Journal of European and Comparative Law, vol. 21, pp. 596-610 [in English].

9. Samuels, A. (2005). A Right to an Oral Hearing in Quasi-Judicial Proceedings? The Cambridge Law Journal, vol. 64, pp. 523-527 [in English].

10. Schabas, W. (2015). The European Convention on Human Rights: a commentary. Oxford: Oxford University Press [in English].

11. Žuber, B. (ed.) (2018). Pomen prakse in zahtev ESČP za izvedbo glavne obravnave v upravnem sporu: študija projekta [Meaning of practice and demands of the European Court of Human Rights for conducting main hearing in an administrative dispute]. Ljubljana: Univerza v Ljubljani [in Slovene].

12. Državni zbor Republike Slovenije (1991). Ustava Republike Slovenije(URS) [Constitution of the Republic of Slovenia]. Retrieved from: http://pisrs.si/Pis.web/pregledPredpisa?id=USTA1 [in Slovene].

13. Državnizbor RepublikeSlovenije(2006).Zakon oupravnem sporu(ZUS-1)[Administrative Dispute Act]. Retrieved from: http://pisrs.si/Pis.web/pregledPredpisa?id=ZAKO4732 [in Slovene].

14. Državni zbor Republike Slovenije (2015). Zakon o zavarovalništvu (ZZavar-1) [Insurance Act]. Retrieved from: http://www.pisrs.si/Pis.web/pregledPredpisa?id=ZAKO6183 [in Slovene].

15. Državni zbor Republike Slovenije (2008). Zakon o revidiranju (ZRev-2) [Auditing Act]. Retrieved from: http://www.pisrs.si/Pis.web/pregledPredpisa?id=ZAKO5273 [in Slovene]. 


\title{
СЛОВЕНСЬКЕ БАЧЕННЯ ГОЛОВНОГО СЛУХАННЯ В АДМІНІСТРАТИВНОМУ СПОРІ
}

\author{
Бруна Жубер, \\ асистент в університеті Любляни, юридичний факультет, \\ старший судовий радник у Верховному суді Республіки Словенія, \\ кандидат юридичних наук, юрист \\ orcid.org/0000-0003-1137-4561 \\ bruna.zuber@pf.uni-li.si
}

\begin{abstract}
Мета. Статтю присвячено чинному законодавству та практичі Республіки Словенія щуодо основних слухань в адміністративному спорі. Крім того, у статті здійснено правовий аналіз прещедентного права Словенії та розглянуто вимоги, встановлені Свропейським судом із прав людини щуодо права на справедливий судовий розгляд, зокрема й права на основне слухання.
\end{abstract}

Методи. Для успішного проведення дослідження автор використовував такі методи наукового пізнання: логічні (аналіз, синтез, індукиію, дедукиію), історичні, системні та формально-догматичні.

Результати. Невід'ємною частиною права на справедливий судовий розгляд $\epsilon$ публічний характер судового розгляду, який у разі адміністративного спору здійснюється на підставі укладеного основного слухання. Його метою є забезпечення демократичного судового розгляду, здійснення громадського контролю над судовим прочесом, а також здійснення права сторін у спорі та інших учасників прочедури на заслуховування в суді. У изй частині обговорюється значення й роль основного слухання в адміністративному спорі. У ньому розглядаються як правові, так $i$ загальні сочіальні причини, які свідчать на користь проведення основного слухання. Аналізуються найбільш важливі рішення Свропейського суду з прав людини та національних судів щзодо прав на основне слухання. Досліджуються статистичні дані Словенського адміністративного суду про проведення основних слухань як показника забезпечення права на справедливий судовий розгляд у Республічі Словенія.

Автор дійшов висновку про те, щзо основне слухання за адміністративним спором має вирішальне значення щуодо здійснення права на змагальну прочедуру та права на справедливу прочедуру.

Висновки. Незважаючи на численні переваги прийняття рішення в адміністративному спорі після завершеного основного слухання, необхідно враховувати те, щзо зобов 'язання прийняття рішення після основного слухання не є абсолютним. Розгляд питання про виключення основного слухання має трунтуватися на критеріях, прийнятих Свропейським судом із прав людини, оскільки вони забезпечують високий рівень захисту основного слухання як права людини.

Ключові слова: основне слухання, адміністративний спір, право людини, адміністративний суд, право на справедливий судовий розгляд, Європейський суд 3 прав людини. 